\title{
The Healing Power of Aesthetics in Music and Art
}

\author{
Irmtraud Tarr \\ Independent Scholar, Rheinfelden, Germany
}

Email address:

irmtraud@tarr-online.de

\section{To cite this article:}

Irmtraud Tarr. The Healing Power of Aesthetics in Music and Art. International Journal of Literature and Arts. Vol. 9, No. 5, 2021, pp. 212-217. doi: 10.11648/j.ijla.20210905.11

Received: August 25, 2021; Accepted: September 17, 2021; Published: September 27, 2021

\begin{abstract}
In this article, the author follows diverse aesthetic, therapeutic and educational facets of musical reception and production. From the levels of meaning of the aesthetic in art, music and music therapy, she draws a bridge to the analogy between the love of music and friendship. In music, art and friendship we can never say everything about them, there is always more to say that can be expressed in words. Because of their individual meaning for us they transcend the boundaries of our knowledge. The love of beauty and friendship opens up listening and musical activity as a physical performance in the devotion to music, in which reflection, experience and action are united. This bodily-aesthetic potential of music can support healing and identity finding in music therapy. Therapeutic work with the medium of music offers sound spaces and resonating spaces that can be experienced by the compulsion of the body and enables one to find one's own aesthetic meaning patterns. It is a matter of finding oneself in music and art with all our senses and to enter into a dialogue through resonance to our own world that we finally can answer the question: Who am I? How do I want to live? How do I want to be?
\end{abstract}

Keywords: Aesthetics, Music, Body, Healing, Friendship, Music Therapy

\section{Introduction}

In this article I follow a variety of aesthetic, therapeutic, and educational issues and facets of musical reception and production. From the levels of meaning of the aesthetics in art and music I discovered a bridge to the analogy between the love of music and friendship. I understand musical doing, listening and friendship as a physical and emotional performance which can support healing and identity finding in music therapy. The individual aspects of this contribution are in associative and not so much argumentative contextual connection put together and give the text the character of a montage.

\section{Aesthetics Is Sensual Perception}

Beauty and the occupation with it doubtlessly belong to mankind. Countless works have already been written about beauty. We remind our readers here pars pro toto about Friedrich Schiller's "Über die ästhetische Erziehung des Menschen" ["Concerning the aesthetic upbringing of mankind"]. "Aesthetics as sensual perceptions of beauty belong to the highest goods" [18]. Although their root, the old Greek word aisthesis, can be translated with sensual perception, aesthetics are often limited to beauty and art. Art, nevertheless, also can contain ugliness, and nature, objects, and rooms can be beautiful [18].

\subsection{Beauty Saves the World}

In this contribution I will be following manifold aesthetic, therapeutic, and educationally based facets of musical reception and production. An arch brings the analogy between the meanings of aesthetics in art and music to the love of music and friendship. I understand musical performance and listening as a kind of corporal performance that can find healing and the finding of one's identity in music therapy. The various aspects of this contribution will be added to one another in an associative (but hardly argumentative) combination and thus give the text the character of a montage.

My point of departure is that we are here in this world to create beauty, for "beauty saves the world" [8] was the opinion of Fyodor M. Dostoyevsky, who saved himself through the power of creativity over his own abysses and the disunions of his time, torn by wars.

If one occupies oneself with the treatment and influencing 
of other human beings by artistic and therapeutic means, it is important to mark the directions and limits that join the areas of treatment, healing, and cultural work that have to do with various professions and problematic settings. In front of the background of psychotherapeutic and art therapeutic theories and practises we should arrive at concepts and attitudes that deliver foundations capable of bearing the load of therapeutic, personality forming, and artistic work. An understanding of the creative-aesthetic dimension can only be won in trade for culture-bearing powers of art, science, and every-day life practise. The background for this is the "anthropology of the creative human being" [19].

\subsection{Aesthetics as Bodily Experience}

Human experience originates in the body, or more exactly, in its various perceptive organs, which from time to time have the possibility of expression. In this article I am concentrating on the expressive power of the ear, which leads to music. The impression leads to expression, whereby the body as perceiver and actor constantly brings forward new forms and shapes. The fascinations and challenges of the path through life, the resonance capability of the self, and the diversity of past experience, all of which have become one's inner world, constantly make new creations possible. They lead to a productive cooperation with other human beings and the things of this world. The creative process has many layers which do not have to end in a product, but lie in the process of creativity itself. Where such processes join together with others arises a happening between us as a relationship, a movement in which we are involved.

For this reason I am using the open way of seeing offered by aesthetics. For me phenomena are in the central point that has to do with beauty - I question them in connection with music therapy and reflect on their importance. Thereby I differentiate two dimensions: the aesthetic reception and the aesthetic production of music [27].

\subsection{What Is Beautiful}

First of all I would like to point to a visual example. The poster by Klaus Staeck (Heidelberg) with the portrait of the mother of Albrecht Dürer, sketched by her son himself [4], fascinates me. It is certainly a remarkable picture of an old lady from the early sixteenth century, to which Staeck provided the question: "Would you rent a room to this woman?" [18]. Most people would answer "no", because the question is provocative and suggestive. However, in a constructivic perspective I would like to point to the fact that beauty is subjective, because perception and evaluation are dependent on the individual. It varies between people, cultures, and times. It is a temporary and controversial phenomenon that is dependent on social and socioeconomic factors [18].

Just like visual art, music makes not only "reality in its entire complexity" perceptible as one of its central formulations of aesthetics [23]. It also formulates a certain distance to its viewers, which once again is a necessary prerequisite for its analysis. Aesthetics thus have a double role: they create comprehension for the formation of their own and others' standard of living and for the discussion of various conceptions of meaning [23].

For Martin Seel, aesthetic perception exposes a higher meaning and a deeper understanding of being. It gives special attention to the moment at hand [22]. Music, in particular, demands "attention to the moment at hand like no other form of expression" [23]. Whoever wishes to listen to it (i. e., to the music of the moment) and to submit to it must remain in the here and now and may not let one's attention wander.

\subsection{Music and Listening}

Many musicians, male and female, complain that the capability of listening is slowly disappearing, because the focussing on one's own ego is detrimental to listening. One must thereby realize that one's own activity is demanded if one wishes to listen to another person [9]. I should welcome the other person, say yes to him in his difference to me, and give him my ear [11]. Listening is giving, and helps the other person to express himself. Making music in music therapy is preceded by one's own listening; it brings the other person to play and invites him to do so [25].

Music unites such diverse doings such as cognitive recognition and reflection, feeling and sensual perception, as well as behavior and doing [23]. It calls out to the listener: Listen to me! Come after me! Make something out of me!

Music is furthermore an important part of cultural expression and leads finally to the question: How do we humans want to live together [2]? How do we want to be to each other, when all the conventional components of similarity, origin, and identity in the aesthetic field of music play no more role, because we meet ourselves here purely as human beings and unquestionability and discover each other in mutual action? These are moments in which all these questionable differences are traversed and translated into acknowledged nearness.

\section{Beauty and Friendship}

Immanuel Kant in particular has penetrated our relationshhip to beautiful things philosophically. We can never say everything about them; there is always more to say that can be expressed in words $[10,16]$. No reason that we can bring forward for the evaluation of beauty can guarantee that another is touched in the same way. We cannot compel anyone to find something beautiful. At the most we can say: "You should also have seen it or heard it." However, it is never possible to explain to others why something is beautiful for us. It is just as impossible to explain why we are a friend to somebody. Something is always missing. We try to grasp what is missing by saying about male or female friends that it is nothing in particular, but rather they are precisely the way they are. It is exactly this which constitutes the friendship with them and move us to friendship with them $[14,16]$.

Similarly we remain true to works of art. They become 
"part of our life. We love them," says the philosopher and literature historian Alexander Nehamas [16]. Works of art that "are important for us" are "inexhaustible" [16]. Because of their individual meaning for us they project over the boundaries of [our] knowledge. This also leads to (selective) separations: "For where one of us discovers an entirely new world the other [person] sees nothing at all" [16].

Unquestionably we humans can fall in love with a melody, a piece of music, even with an entire symphony. To fall in love seems for Nehamas an appropriate expression for the relationship to a musical work of art as well. Even though a marriage with it is not possible, being happy with it "until death us do part" [16] is a realistic option.

Nehamas sees the love of music in analogy to the love between persons. Just as between two human beings, a particular piece of music can bring forward "an intoxicating feeling" [16] between it and its lover, male or female. It implies "that between us everything will go well, even though we cannot say why, as long as it occupies a place in our life" [16]. It is therefore no wonder that music can make listeners and players spontaneously happy and can change them. Often it leaves us human beings with another view of oneself and the world.

This statement can also be confirmed socialpsychologically, for music proceeds with the human tendency to look self-evidently for the partnership of others ("affiliation" [15]). According to the Integrative Theory, which accepts music therapeutic concepts among others, music is also valid as a transitional object and transitional medium [28].

In addition, the beauty of a musical work of art moves not only the individual, according to Nehamas: "We have the feeling that there is a suspicious difference between our liking for particular directions of taste - our reaction to things about which we say 'one cannot argue about taste' - and our reaction to things that we do not find terrific or pretty, but regard as beautiful. It is especially with art that we tend to take our reasons much too seriously to imagine that they in fact have meaning only for us" [16].

Taste is subjective

Immanuel Kant hit the dilemma of aesthetic judgment on the head in his criticism of the power of judgment [10]. A work of art can allow exceptions, but an argument about subjective judgments of taste is hardly possible. Here we see "the antimony of the aesthetic judgment of taste" [16, 10]. For the Königsberg philosopher the impression arises that something is beautiful, not because of any attribution of the work of art itself, but from the subjective feeling of pleasure that it arouses in us. Other than sensual liking (we think of the taste of chocolate!) this is owing to the harmonic relationship of mental images and realization competences that every person has at his disposal. For this reason a judgment of taste, as subjective it may be, can be valid for all persons. Kant's statement is thus to be taken with a grain of salt. Every aesthetic judgment may be subjective, but everyone does not have to agree with it. Whether or not something is beautiful is not only an individual finding, but it is also not simply generalizable. If I find something to be beautiful, I hope that others will agree - but quite certainly "only some others" [16]. I invite these people to share my enthusiasm. To be sure, if every man and woman would take over precisely my own judgment of taste, I would probably not be overjoyed.

The same is true of friendship: We love art and friends in similar ways, but we do not love all human beings, but selectively: some yes, the others not. Here, too, I am taking over Nehamas' ideas: universal friendship is to be wished for, just like universal beauty - although not absolutely - because that could bring about the end of individuality. "That which we find to be beautiful is - like our friends - that which we love" [16].

Friendship arises in differences in the eye of our friend, male or female. "The values of love are to be found precisely in the space that separates us from those persons with whom we otherwise are joined by universal ties" [16]. Here we can by all means speak of a kind of room for love which originates on the basis of the differences between human beings. Nehamas is positively in favor of forming each friendship individually. It belongs to the "most important possibilities for individualization that we have at our disposal" [16] I can only agree with this.

\section{Aesthetic Perception and Bodily Resonance}

Back to music: aesthetic perception is an intrinsic part of our entry to the world, and always more than simple understanding. Whoever listens to a piece of music with others is tied up in a mutual verbal and nonverbal expressive performance. I was able to experience such an exceptional "accomplishment of the audience" [23] in a festival concert with 15 tractors, organ, and singing. The concert began in front of the church, in a polyphonically moved and moving transit area. First of all excitement prevailed, curiosity - this performance was too unusual. With time, however, it was possible through the newness and "otherness" to widen and alienate the possibilities of aesthetic perception and in this way to stimulate learning and understanding. For this reason it was possible after this concert to exchange opinions in form of spoken and nonspoken explanations, in that we remained together, discussed, and ate together. The mutual experience of this thrilling event allowed one's own opinion to recede and opened for us a new world of sound, entering this event into the conversation.

Aesthetic perception and production also have a corporal aspect that is often overlooked [5]. For example, whoever sings along in a choir experiences in splendid moments a deep resonance between his own body and his mental condition, between himself and his colleagues. Here in a church or concert hall appears a divided resonance room. There is hardly anyone there who does not feel what it means to participate, to concentrate, and to feel resonance with the others. That people can introduce resonance in- and outside 
with their voices or instruments makes it a likely factor for understanding music. No other - surely no aesthetic phenomenon at all - is distributed in this way and is so effective for the establishment and healing of subjective relationships with the world [25]. Music thus can be understood as a form of corporal art, even if nobody is physically touched thereby. It is "accessible to aesthetic perception, for aesthetic thinking needs observation. It is a corporal procedure that is carried out by various senses" [23]. In one's body, making music and in listening to music, exists a resonance room. Aesthetics consummate themselves via the body [5].

\subsection{Art Needs Passion}

I refer to Nietzsche's confession of faith in art: "Truth is repulsive. We have art so that we do not get to the root of truth" [17]. According to Liessmann [12], who has occupied himself extensively with Nietzsche's assessment, art also includes the will to a different way of seeing, the will to illusion, to appearance, from which every artistic creativity lives. He who lives intensively for art would like to bring forth a new and different world. Male and female artists work, live, and feel in this way - with the passion and the will to create something new, in order to see the world with other eyes. Therein lies the chance, the greatness, and also the danger of the passionate "burning" of creative people. For Nietzsche, for example, the world gains a meaning only as aesthetic appearance. Nowadays music has the task "of being the heir to lost religiosity and in its aestheticism to give our being that meaning [which our wounded planet] perhaps has lost long ago" [12].

For this reason musicians' creativity is something that makes sense, not only something that satisfies the basic necessities of work, entertainment, and provocation. For musicians, male and female, who make music not only for the money, nothing has changed. For them it is a matter of expression - of art. Passion is absolutely necessary for music making, if art is to be something more than making our beliefs heard. Only in the area of aesthetics, in art, is passion truly possible, justified, and necessary, because its gleaming character allows this passion free reign. It is the "wish for appearance, for illusion" [17] that presents the innermost part of artistic creation [12]. Whoever is burning for art, whoever would like passionately to bring forth a world, for him or her it is a matter of art [13]. "Art is meaning and meaning is power" [7]: to give color to the sounds, to bring order to the chaos, to bring ground to the empty space under one's feet, from being guilty to shovel treasures. Here it is a matter of something fundamental and healing.

\subsection{Music Therapy as Playground}

Music therapy, too, brings us into the realm of aesthetics. This is the place where it is a matter of something new, unpredictable, and meaningful. It offers every client, male or female, a room in which to test oneself musically. Its offer is: This is your playroom which up to now was not seen or perceived. In the final analysis it is a matter of opening up new playrooms, which are to be filled with meaning [24].

The music rooms are also new for me as therapist in every session. They are meaningful because the personal style of the one facing you expresses itself and is allowed to do so. They are aesthetic, because nothing could bring the other person to see it in exactly the same way. The writer and philosopher Henry David Thoreau said: "[...] you know more about a person who truly interests you than anybody could tell you. A glance, a gesture, a deed that is meaningless for others, tells you more than any words" ([26] quoted after [16].

Such playrooms open up because of four simple questions: When did you stop singing? When did you stop telling stories? When did you dance the last time? When did you enjoy silence for the last time? These questions might sound commonplace. Finally, however, they contain the four ingredients of beauty: play, dance, be still, tell stories. And they contain the dimensions of healing, becauses crises can also happen hand in hand with creative injuries.

It is also possible to make this relationship become visible in music therapy, in that one paints a life panorama with reference to these four questions or aspects and finds surprising results. I maintain that the four ingredients of beauty - especially music - are the mother tongue of aesthetics. Why? With music we can dance or sing away our troubles as with no other art. Music as a call into self-denial and as a feeling of fullness means: that which was not yet here that we were yearning for we can produce with singing or playing, even when only our mouth and hands move and our heart is not yet participating. This is the way to open up our hearts from outside to inside. Sometimes our playing hands and our singing mouth move after our heart.

"Cheer up, my heart, sing and jump and be of good courage" ["Wohlauf, mein Herz, sing und spring und habe guten Mut!", 6] it is said in the hymnal. Sometimes the mouth sings first, until the soul follows. Think of the example in Johann Sebastian Bach's famous cantata "Ich hatte viel Bekümmernis" (BWV 21), in which both can be found - the distress that Bach felt in the face of the loss of his wife, and the consolation expressed in the words: "Your refreshments comfort my soul" ["Deine Erquickingen trösten meine Seele"].

\subsection{Expression of New Meaning}

I think, too, of a friend who was involved in a severe accident and since then cannot remain seated for any length of time. He says: "Since my accident I cannot remain in my place. I have to walk, but this walking has brought me to places that I had never hoped about. I am capable of hearing what the quietness tells me on my footpaths and I hear inner melodies. I hum to myself, and since then I've found my inner beauty." Sprouts shoot from every one of his senses.

What is beautiful about music is that we can sing and express new meanings this way, without deteriorating into the pressure of a solution or a forced meaning. The dispairing accusation and the feeblest cry for help presuppose that someone is listening who can be trusted [25]. Making music 
thereby means giving a message to ourself, about ourself, and to others [20]. Think of the deep emotional impression produced by an interpretation of Maria Callas - I believe that no dispute about this or that meaning of aesthetics disappear when we have heard her. Why? "She not only sang her roles, she also lived on the razor's edge", thus the poetess Ingeborg Bachmann.

We hear if music is a revelation of life as lived inside, because it reveals the nature of feelings in a way that speech cannot approach. In music I know that I am not "my own giver of meaning" and I also do not have to be my only "savior" [24]. "I can sing forward that which is not yet here, and I can praise or esteem highly for its beauty that which is here" [24]. Precisely this gives our life playfulness and lightness.

\subsection{Experience of Otherness}

People need something completely different where the pressures of daily life loosen: rooms of expression of yearning, of the power of imagination and of beauty. I think that we could interpret what Josef Beuys formulated with "Everyone is an artist" [1], perhaps in the way that humans need rooms in which they can experience reality in the way that male or female artists witness. They are rooms that make us ourselves, the world, and our relation to it discoverable, in the possibility of being different.

The realization of this practise would indeed be for me that which I could designate as a piece of refusal of the expectations of daily life. It would be for me that which I like to call "find beauty again". "Aesthetic education can be seen as the arrangement of therapy, as a corrective of institutional education, as an act of emancipation [...]" [23]. Its uniqueness consists therein, that it occupies itself with creative performances and concepts of the subject of him- or herself and the "world", with "world designs" [23]. With this it compensates for the tendency of developing individual competences only for use in business and society. Music, as a form of becoming oneself aesthetically, healing, and educationally, holds in readiness multifarious playrooms in which the subject can offer itself pointlessly to its own presence [23]. For this reason it cannot be thought to be absent as the basis for therapeutic and educational processes.

\subsection{How Do We Want to Live}

Like all art, music is made "because of itself" [23]. Of all the tasks it is asked to perform, the aesthetic mandate is certainly the most important. Music making and listening to music are more than technique; music makes sense and opens up meaning to subjective "world experience and world interpretation" [29] in all its gradations of color. It allows creative configurations in the aesthetic proof room. One can simply pause, it allows the experience of new feelings, in it emerge other and new ideas for forming one's life, it challenges one to look at it from another angle. If I hear something beautiful or make music myself, I observe myself with my "ich" and my body and find myself in resonance with my (and also others') existence. It is essentially a matter of finding oneself in the music with all one's senses, to express oneself aesthetically, and to enter into it in a dialogue, for it is through resonance to our own world that we finally become who we are.

Finally it is a matter, also in music therapy, of the questions: How do I want to live? How do I want to be? How do we want to live? How do we want to be?

\section{Conclusion}

Music, like all art, is created for its own sake. Of all tasks that are assigned to music and art, the aesthetic task is certainly the most important, because it opens up world experience and world interpretation. When people hear or create beautiful things, they perceive themselves and their bodies in resonance with their own and other people's world. It is essentially to feel yourself in music with all your senses, to express yourself aesthetically and with it to enter into a dialogue, because through resonance to our own living environment we become who we are. From an aesthetic point of view, music and friendship are ultimately about existential questions: How do I want to live? How do I want be?

\section{References}

[1] Beuys, J. (2002). Sprechen über das eigene Land: Deutschland. Rede vom 20. November 1985. Wangen: FIUVerlag.

[2] Bieri, P. (2011). Wie wollen wir leben? St. Pölten, Salzburg Residenz.

[3] Bischof, W. F. (Ed.) (1997-2016). Johann Sebastian Bach: Ich hatte viel Bekümmernis. BWV 21. Zugriff am 09.01.2019. Verfügbar https://webdocs.cs.ualberta.ca/ wfb/cantatas/21.html.

[4] Blum, G. (2008). "Vorsicht Kunst". Die Fotomontagen von Klaus Staeck. In: Paul, G. (Hrsg.). Das Jahrhundert der Bilder, Bd. 2, Göttingen 2008, S. 418-425. Zugriff am 10.01.2019. Verfügbar unter https://archiv.ub.uniheidelberg.de/artdok/1568/1/Blum_Vorsicht_Kunst_Die_Foto montagen_von_Klaus_Staeck_2008.pdf.

[5] Böhme, G. (1995). Atmosphäre. Aufsätze zur neuen Ästhetik. Frankfurt: Suhrkamp.

[6] Evangelische Landeskirche in Württemberg (Hrsg.) (2007). Evangelisches Gesangbuch. Ausgabe für die Evangelische Landeskirche in Württemberg. Stuttgart: Gesangbuchverlag.

[7] Foucault, M. (20Blum07). Ästhetik der Existenz. Frankfurt: Suhrkamp.

[8] Grübel, R. G. (2001). Literaturaxiologie. Zur Theorie und Geschichte des ästhetischen Wertes in slavischen Literaturen. Wiesbaden: Harrassowitz Verlag.

[9] Han, B.-C. (2016). Die Austreibung des Anderen: Gesellschaft, Wahrnehmung und Kommunikation heute, Frankfurt am Main: S. Fischer.

[10] Kant, I. (1986). Kritik der Urteilskraft. Stuttgart: Reclam. 
[11] Lévinas, E. (2007). Die Spur des Anderen. Untersuchungen zur Phänomenologie und Sozialphilosophie. Freiburg im Breisgau: Alber.

[12] Liessmann, K. P. (2013). Philosophie der modernen Kunst. Neuausgabe. Wien: Facultas.

[13] Liessmann, K. P. (2018). Brennen für die Kunst. Die Leidenschaft der Kreativen. Vortrag im Salzburger Nachtstudio 29.08.2018. Zugriff am 06.01.2019. Verfügbar unter https://oe1.orf.at/programm/20180829/524218.

[14] Montaigne de, M. (2005). Von der Freundschaft. München: dtv.

[15] Müller, M. \& Petzold, H. G. (2003). Affiliation, Reaktanz sozialpsychologische Beziehungsmodelle und ihre Bedeutung für die Praxis der Supervision. In: Supervision: Theorie Praxis - Forschung. Eine interdisziplinäre Online-Zeitschrift Ausgabe 08/2003, S. 1-13. Zugriff am 13.05.2019. Verfügbar unter https://www.fpipublikation.de/images/stories/downloads/supervision/MuellerPetzold-Affiliation-Supervision-08-2003.pdf.

[16] Nehamas, A. (2017). Über Freundschaft. München: dtv.

[17] Nietzsche, F. (1988). Kritische Studienausgabe 13: Nachgelassene Fragmente 1887-1889. Berlin: de Gruyter.

[18] Nuissl, E. (2014). Ist Ästhetik erlernbar? Ein Essay über Ästhetik, Reflexion, Freiheit und Widerstand. In: Magazin erwachsenenbildung.at. Das Fachmedium für Forschung, Praxis und Diskurs. Ausgabe 22, 2014. Wien, S. 04-1- 04-9. Zugriff am 09.01.2019. Verfügbar unter: http://www.erwachsenenbildung.at/magazin/14-22/meb1422.pdf.

[19] Orth, I. \& Petzold, H. G. (2000). Integrative Therapie: Das "biopsychosoziale" Modell kritischer Humantherapie und Kulturarbeit - ein, lifespan developmental approach. Theorie, Praxis, Wirksamkeit, Entwicklungen. In: POLYLOGE Materialien aus der Europäischen Akademie für biopsychosoziale Gesundheit. Eine Internetzeitschrift für "Integrative Therapie" (peer reviewed), 08/2000. Erschienen in: Integrative Therapie 2/3, S. 131-144. Zugriff am 13.05.2019. Verfügbar unter https://www.fpipublikation.de/images/stories/downloads/polyloge/orthpetzold-2000-integrative-therapie-biopsychosoziale-modellkritische-humantherapie-polyl-08-2000.pdf.

[20] Petzold, H. G. (2004). Der "informierte Leib im Polylog “. Ein integratives Leibkonzept für die nonverbale/verbale Kommunikation in der Psychotherapie. Erschienen in: Hermer, M. \& Klinzing, H. G. (2004). Nonverbale Kommunikation in der Psychotherapie. Tübingen: dgtv, S. 107-156. Zugriff am
08.01.2019. Verfügbar unter https://www.fpipublikation.de/images/stories/downloads/textarchivpetzold/petzold-2004h-informierte-leib-im-polylog-einintegratives-leibkonzept-in-der-psychotherapie.pdf.

[21] Schiller, F. (2012): Über die ästhetische Erziehung des Menschen in einer Reihe von Briefen. (1. Ausgabe 1801). Stuttgart: Reclam Ebook.

[22] Seel, M. (2007): Ein Schritt in die Ästhetik. In: M. Seel (Hrsg.): Die Macht des Erscheinens. Texte zur Ästhetik. Frankfurt am Main: Suhrkamp, S. 11-26.

[23] Stoeckler, E.-M. (2014). Musik hören - Zeit für den Augenblick haben. Ästhetische Wahrnehmung, Erfahrung und Bildung in der digitalen Gegenwart. In: Magazin erwachsenenbildung.at. Das Fachmedium für Forschung, Praxis und Diskurs. Ausgabe 22, 2014. Wien, S. 05-1 - 05-9. Zugriff am 09.01.2019. Verfügbar unter http://www.erwachsenenbildung.at/magazin/14-22/meb1422.pdf.

[24] Tarr, I. (2010). Leben macht Sinn. Was uns bewegt und weiterbringt. Stuttgart: Kreuz.

[25] Tarr, I. (2016). Resonanzen. Leben macht Sinn: Was uns bewegt und weiterbringt. Freiburg: Herder.

[26] The Walden Woods Project - The Thoreau Institute at Walden Woods (Eds.) (2009). Thoreau, Henry David: Journal XI: July 2, 1858 - February 28, 1859. Zugriff am 06.01.2019. Verfügbar unter: https://www.walden.org/wpcontent/uploads/2016/02/Journal-11-Chapter-8.pdf.

[27] Thies, C. (2004). Grundwissen Ästhetik, 1. Teil: Was ist Ästhetik? Proseminar: Schönheit, was ist das? (WS 2003/04). Passau: Universität Passau. Zugriff am 10.01.2019. Verfügbar unter https://www.phil.unipassau.de/fileadmin/dokumente/lehrstuehle/thies/onlineWas_ist_Aesthetik.pdf.

[28] Wiesmüller, E. (2005). Zum Umgang mit den Begriffen Übergangsobjekte und Objektbesetzungen in der Musiktherapie. In: Musiktherapeutische Umschau Online. Zugriff am 14.05.2019. Verfügbar unter $\mathrm{http} / / /$ www.musiktherapie.de/fileadmin/user_upload/medien/p df/mu_downloads/wiesmueller_uebergangsobjekte.pdf.

[29] Woyke, A. (2004). Die Entwicklung einer aprozessualen Weltund Naturdeutung in der abendländischen Geistesgeschichte und ihre Bedeutung für die "Ausblendung des Prozessualen" in Chemie und Chemieunterricht. Dissertation zur Erlangung des Grades eines Doktors der Pädagogik, Siegen: Universität Siegen. Zugriff am 11.01.2019. Verfügbar unter https://dnb.info/973536500/34. 